\title{
PLATELET CONCENTRATES- PREPARATION PROTOCOLS AND RECENT ADVANCES
}

\section{Dental Science}

Dr. Prathamesh Fulsundar*
PG Resident-Dept of Prosthodontics, Bharati Vidyapeeth Dental College \& Hospital, Pune. ${ }^{*}$ Corresponding Author

Dr. Vijaysinh More Professor-PG Guide, Bharati Vidyapeeth Dental College \& Hospital, Pune.

\section{ABSTRACT}

Autologous blood derivatives are surgical biologic additive that are prepared by manipulation of autologous blood. Platelet rich fibrin is one of the most commonly used blood derivatives in dentistry. Blood derivatives have several advantages such as being $100 \%$ autogenous, cost effective, less time consuming, simple to perform and with superior \& prolonged release of growth factors.

Since inception there has been evolution of various techniques, in-depth research regarding its biological actions, clinical applications.

Several modifications have been advocated in the conventional protocol like the advanced PRF, injectable PRF, PRF lysate and Titanium-prepared PRF. Hence, the aim of this article is to review various types and properties of blood derivatives and the advancement in the PRF technology since its inception.

Furthermore, platelet concentrates are safe, reliable and cost-effective means to accelerate tissue healing and for improving the efficiency of tissue repair after injury.

\section{KEYWORDS}

Platelet Rich Fibrin, Dental Implants, Growth Factors.

\section{INTRODUCTION}

The growing multidisciplinary field of tissue engineering aims at predictably repairing, regenerating or restoring damaged and supporting tissues. This includes cell, tissue and organs, due to an assortment of biological conditions, involving congenital abnormalities, injury, disease and aging.

Autologous blood derivatives such as PRF and PRP, have been used for regenerative procedures in various fields of medicine and dentistry, including plastic surgery, reconstructive surgery, and dermatology, to deliver greater concentrations of autologous growth factors directly to host tissues. These growth factors have been shown to be chemotactic for various cell types, including monocytes, fibroblasts, endothelial cells and stem cells. Thus creating tissue micro-environments and directly influencing the proliferation and differentiation of progenitor cells. [1]

\section{DISCUSSION:}

\section{Evolution of Blood Derivatives}

The development of platelet concentrates finds its origin in the concept of fibrin adhesives

\section{Table 1 - Evolution of platelet concentrates.}

\begin{tabular}{|l|l|l|l|}
\hline Name & Proposed by & Technique & Drawbacks \\
\hline $\begin{array}{l}\text { Platelet } \\
\text { concentra } \\
\text { tes }\end{array}$ & 1970 's & $\begin{array}{l}\text { Donor plasma } \\
\text { which was then } \\
\text { mixed with } \\
\text { thrombin and } \\
\text { calcium which led } \\
\text { to polymerization of } \\
\text { fibrinogen }\end{array}$ & $\begin{array}{l}\text { Poor stability or risk } \\
\text { of disease } \\
\text { transmission in case } \\
\text { of commercially } \\
\text { available products }\end{array}$ \\
\hline $\begin{array}{l}\text { Autologo } \\
\text { us } \\
\text { fibrin } \\
\text { glue }\end{array}$ & $\begin{array}{l}\text { Tayapongsak } \\
\text { Pre-operative (one } \\
\text { to three week } \\
\text { before procedure) } \\
\text { collection of blood } \\
\text { followed by around } \\
\text { 30 minutes } \\
\text { (ammonium } \\
\text { sulphate } \\
\text { precipitation } \\
\text { technique) to 48 } \\
\text { hours } \\
\text { (cryopecipitate } \\
\text { technique) of } \\
\text { handling. }\end{array}$ & $\begin{array}{l}\text { Technique was long } \\
\text { and complex. The } \\
\text { amount of } \\
\text { concentrate obtained } \\
\text { was quite less as } \\
\text { compared to the } \\
\text { amount of blood } \\
\text { collected (2ml from } \\
75 \text { ml blood in } \\
\text { ammonium sulfate } \\
\text { concentrate technique } \\
\text { and 10-15ml } \\
\text { concentrate from } \\
\text { 250ml of blood). }\end{array}$ \\
\hline
\end{tabular}

\begin{tabular}{|c|c|c|c|}
\hline $\begin{array}{l}\text { Platelet } \\
\text { rich } \\
\text { plasma }\end{array}$ & $\begin{array}{l}\text { Whitman } \\
1997\end{array}$ & $\begin{array}{l}\text { Double centrifugation of } \\
\text { autologous blood with } \\
\text { anticoagulant. It consisted } \\
\text { of a soft spin followed by } \\
\text { which the blood would } \\
\text { separate into red } \\
\text { corpuscular base, buffy } \\
\text { coat and the platelet poor } \\
\text { plasma. The last two } \\
\text { components were aspirated } \\
\text { and re centrifuged at a hard } \\
\text { spin after which PRP was } \\
\text { collected. }\end{array}$ & $\begin{array}{l}\text { In few cases } \\
\text { Bovine thrombin } \\
\text { could give rise to } \\
\text { life threatening } \\
\text { coagulopathies. } \\
\end{array}$ \\
\hline $\begin{array}{l}\text { Plasma } \\
\text { rich } \\
\text { in growth } \\
\text { factors }\end{array}$ & $\begin{array}{l}\text { Anitua \& } \\
\text { co- } \\
\text { workers } \\
1999\end{array}$ & $\begin{array}{l}\text { Autologous blood with } \\
\text { anticoagulant was } \\
\text { centrifuged at } 460 \mathrm{G} \text { for } 8 \\
\text { minutes and this resulted } \\
\text { in collection of } \\
\text { plasma rich in growth } \\
\text { factors (PRGF) at the } \\
\text { bottom of the tube. This } \\
\text { PRGF was then taken from } \\
\text { the bottom of the tube and } \\
\mathrm{CaCl}_{2} \text { was added ( } 0.05 \mathrm{ml} / \\
\text { ml of PRGF). This led to } \\
\text { coagulation in around } 10 \\
\text { minutes and a gelatinous } \\
\text { PRGF was obtained. }\end{array}$ & $\begin{array}{l}\text { Led to incomplete } \\
\text { activation of } \\
\text { platelets and low } \\
\text { levels of growth } \\
\text { factors release. } \\
\end{array}$ \\
\hline
\end{tabular}

\section{Different types of autologous blood derivatives}

The different platelet concentrates can be classified into four categories, depending on their leucocyte and fibrin content:

- Pure platelet-rich plasma(P-PRP)

Example: cell separator PRP, Vivostat, Anitua's PRGF.

\section{- Leucocyte- and platelet-rich plasma (L-PRP)}

Example: Curasan, Regen, Plateltex, SmartPReP, PCCS, Magellan or GPS PRP.

\section{- Pure platelet-rich fibrin (P-PRF)}

Example: Fibrinet.

- Leucocyte and platelet-rich fibrin (L-PRF)

Example: Choukroun's PRF.

This classification will help determine different reasons for success and failure of technique, along with providing a new approach for development of newer techniques. 


\section{Table 2. PRF preparation protocols}

\begin{tabular}{|l|l|l|l|l|}
\hline Type of PRF & $\begin{array}{l}\text { Proposed } \\
\text { by }\end{array}$ & RPM & $\begin{array}{l}\text { Time } \\
\text { (Minutes) }\end{array}$ & Tube \\
\hline $\begin{array}{l}\text { Leukocyte \& } \\
\text { Platelet rich Fibrin } \\
\text { (L-PRF) }\end{array}$ & $\begin{array}{l}\text { Choukroun } \\
(2004)\end{array}$ & 2700 & 12 & Glass coated tube \\
\hline $\begin{array}{l}\text { Advanced platelet } \\
\text { rich fibrin } \\
\text { (A-PRF) }\end{array}$ & $\begin{array}{l}\text { Ghanaati } \\
(2014)\end{array}$ & 1300 & 14 & Patented \\
\hline $\begin{array}{l}\text { Injectable platelet } \\
\text { rich fibrin } \\
\text { (I-PRF) }\end{array}$ & $\begin{array}{l}\text { Mourao } \\
(2015)\end{array}$ & 700 & 3 & Non coated \\
\hline $\begin{array}{l}\text { Advanced platelet } \\
\text { rich fibrin Plus } \\
\text { (A-PRF+) }\end{array}$ & $\begin{array}{l}\text { Fujioka- } \\
\text { Kobayashi, } \\
\text { Miron } \\
\text { (2016) }\end{array}$ & 1300 & 8 & Same as A-PRF \\
\hline
\end{tabular}

\section{Protocol for different PRF preparations}

The classic PRF protocol was suggested by Choukroun \& coworkers (Table 2). The basic protocol of producing PRF includes centrifugation of freshly drawn blood without any anticoagulant in glass based collection tubes which results in formation of three layers i.e. red blood corpuscles at the bottom, platelet poor plasma at the top and PRF in between. The same protocol has been modified to obtain A-PRF and iPRF by modifying the centrifugation speed, time and the tube in terms of its design and material which the PRF is produced. [2]

\section{Recent Advances in PRF}

PRF as a biologic surgical additive has been successfully used for varied applications in dentistry. Since inception there has been evolution of various techniques, in-depth research regarding its biological actions, clinical applications. Several modifications have been advocated in the conventional protocol like the advanced PRF, injectable PRF, PRF lysate and Titanium-prepared PRF.

\section{Advanced PRF}

Leukocyte and PRF (L-PRF) is produced at a speed of $2700 \mathrm{rpm}$ for 12 minutes in sterile glass based plastic tubes. [3] For formation of APRF, slower speed (1500 rpm) and more time (14 minutes) is used in sterile plain glass-based vacuum tubes (A-PRF10 tubes)

The authors propose that such a protocol leads to enhanced B \& Tlymphocyte entrapment, more even distribution of platelets, neutrophils. Also, the number of viable cells including platelets is much higher in A-PRF. There is better deployment of resident monocyte, macrophages and lymphocytes. [4] Clinically, this would be beneficial as it would translate into increased amount of growth factor and cytokine release. However, some studies have provided contradictory results.

\section{Advanced PRF+}

Fujioka-Kobayashi (2016) suggested another modification of A-PRF, by reducing centrifugation time $(1300 \mathrm{rpm})$ to 8 minutes called as APRF+. [5]

The authors argue that less time would result in a decrease in the amount of forces that the cells of the blood would be exposed to \& hence, would increase the cells content of the PRF matrix. When they assessed the PRF produced by this protocol to L-PRF and A-PRF in terms of growth factor release, biocompatibility \& cellular activity, they observed that A-PRF+ demonstrated highest release of PDGF, TGF- $\beta 1$, EGF and IGF

\section{Injectable PRF}

One of the latest developments in the PRF technology is the production of injectable PRF (i-PRF). As compared to PRP, one drawback that limits the applications of PRF is that PRF is obtained as a gel form which is not conducive to be injected.

For preparation of i-PRF, blood is collected in plastic tubes without any anticoagulants and centrifuged for 3 minutes at 700rpm. [6]

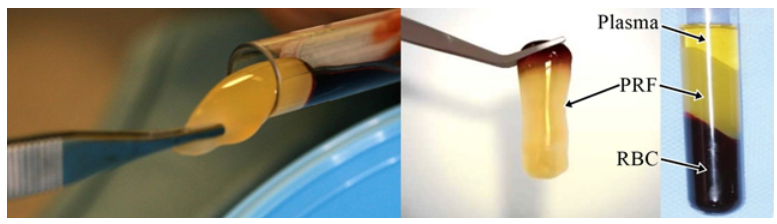

Figure 1. PRF layer collected in test tube. 
7. Sohn DS, Huang B, Kim J, Park WE, Park CC. Utilization of autologous concentrated growth factors (CGF) enriched bone graft matrix (sticky bone) and CGF-enriched fibrin membrane in implant dentistry. J Implant Advanced Clin Dent 2015;7:11-8.

8. He L, Lin Y, Hu X, Zhang Y, Wu H. A comparative study of platelet-rich fibrin (PRF) and platelet-rich plasma (PRP) on the effect of proliferation and differentiation of rat osteoblasts in vitro. Oral Surg Oral Med Oral Pathol Oral Radiol Endod 2009;108:707-713.

9. Wirohadidjojo YW, Budiyanto A, Soebono H. Platelet-Rich Fibrin Lysate Can Ameliorate Dysfunction of Chronically UVA-Irradiated Human Dermal Fibroblasts. Yonsei Med J 2016;57:1282-5.

10. Tunalı M, Özdemir H, Küçükodacı Z, Akman S, Yaprak E, Toker H et al. A novel platelet concentrate: titanium-prepared platelet-rich fibrin. Biomed Res Int 2014;209548

11. Ustaoğlu G, Ercan E, Tunali M. The role of titanium-prepared plateletrich fibrin in pang $\mathrm{G}, \mathrm{E}$ E, Tunal M. The role of titanin-prepared platetich fibrin in 